\title{
SPE-LC/MS/MS Method for Detection of Antidiabetic Contaminants in Municipal and Rural Wastewater
}

\author{
VASILE-ION IANCU ${ }^{1,2 *}$, GABRIEL-LUCIAN RADU ${ }^{2}$, ROXANA SCUTARIU', \\ LAURA-FLORENTINA CHIRIAC ${ }^{1}$, TOMA GALAON ${ }^{1}$, JANA PETRE ${ }^{1}$ \\ ${ }^{1}$ National Research and Development Institute for Industrial Ecology-ECOIND, 71-73 Drumul Podu Dambovitei Str., \\ Bucharest, \\ ${ }^{2}$ University Politehnica Bucharest, Faculty of Applied Chemistry and Materials Science, 1-7 Polizu Str., 011061, \\ Bucharest, Romania
}

\begin{abstract}
Antidiabetic drugs are among the most prescribed and consumed pharmaceuticals worldwide. Their occurrence in environment was little investigated due of lack of analytcial methods for their detection in waters. In this work has been developed a selective SPE-UHPLC/MS/MS method for isolation, identification and quantification of some antidiabetic compounds. The 3 selected analytes (glyburide, glimepiride and repaglinide) were separated on Eclipse C18 LC column at $30^{\circ} \mathrm{C}$ using isocrat elution with mobile phase of acetonitrile: $0.04 \%$ acetic acid $(60 / 40, v / v \%)$. The optimal flow rate was $0.2 \mathrm{~mL} / \mathrm{min}$ and the injected volum was $10 \mu \mathrm{L}$. The contaminants were detected in negative electropray ionization mode (ESI-) by Multiple Reaction Monitoring (MRM). Collision energy, fragmentor voltages were optimized to obtain high sensitivity. Optimization of SPE-LC-MS/MS parameters gave low quantification limit values between 0.27 and $11.1 \mathrm{ng} / \mathrm{L}$. The organic pollutants were isolated from waste water samples on Strata C18 cartridges. The linear regressions were drawn in the interval of 1-100ng/L with good determination coefficients. Spike recovery rates were between 74.5 and $88.2 \%$ for waste water, with satisfactory precisions $(R S D<15)$. the method was applied to analyze real influent and effluent of wastewater treatment plant (WWTP) samples.
\end{abstract}

Keywords: antidiabetic contaminants, liquid chromatography-mass spectrometry, wastewater

Over the last decades, pharmaceutical compounds have become an important topic in environmental studies, and are a source of concern for environmental specialists, due primarily to the accelerated increase in drug use, demographic change and drug development. It is estimated that about 3,000 different substances are used today as pharmaceutical ingredients worldwide. However, only a small subset of these compounds $(\sim 150)$ has been investigated in environmental studies [1]. Widely used antidiabetics include sulfonylureas (glibenclamide, gliclazide, glimepiride); biguanides (metformin); meglitinides (repaglinide) and alpha-glucosidase inhibitors (acarbose) [2]. The number of people suffering from diabetes is steadily increasing, being over 360 million worldwide. In Romania, data show that over 500,000 diabetic patients were registered in 2010, and in 2011 the estimates exceed 600,000 [3]. Metformin is the most recommended drug in controlling type 2 diabetes due to its high efficiency, sustainability, low cost, and ability to reduce glycemia [4]. In Germany and the United States, the daily prescribed dose of metformin has tripled in recent years, reaching about 1100 tones in Germany and 2,400 tons in the United States in 2010. This accelerated consumption of antidiabetics has increased their concentration in the environment.

In Europe, a number of policies and directives have been applied to protect the environment from exposure to chemicals. EU Decision 840/2018 introduces 6 pharmaceuticals into the European Union's monitoring plan for the environment, namely a non-steroidal anti-inflammatory drug diclofenac, 3 macrolide antibiotics (azithromycin, clarithromycin, erythromycin), 1 synthetic hormone (17-alpha ethinyl-estradiol EE2), 1 natural hormone (17 beta estradiol) [5]. After administration, active pharmaceutical compounds undergo metabolic processes in the body. Significant fractions of the parent compound are excreted in the non-metabolized form or as metabolites (active or inactive, hydroxylated or carboxylated) in sewage treatment and waste water treatment systems [6, 7]. A 2014 study on biodegradation and transformation into water and / or sediment systems concluded that pharmaceutical products are not complete degraded and degradation products that are more persistent than parent compounds [8] can be observed. Furthermore, many of the pharmaceuticals do not degrade during wastewater treatment processes in municipal WWTPs and they are therefore discharged into receiving surface waters, thus constituting major sources of contamination [914]. The antidiabetic compounds contain an acidic function ( $\mathrm{N}-\mathrm{H}$ group of sulfonamide moiety and/or a $\mathrm{COOH}$ group) and are assumed that they are weak acids [15]. At pH 7.4 their sulfonamide group is completely ionized. Considering their octanol-water partition coefficients ( $\log \mathrm{K}_{\mathrm{ow}}$ 3.9-6.8) antidiabetics are lipophile drugs.

*email: vasileiancu10@gmail.com,040214100377 
The aim of this work was to develop a new sensitive and selective SPE-LC/MS/MS method for the extraction and quantification of some antidiabetic contaminants in waste water samples and to evaluate their removal rate. This is the first national study about the antidiabetic's occurrence in Romanian WWTPs. First the method was optimized for some working parameters of selective C18 solid phase extraction (SPE) and liquid-chromatograph equipped with QQQ (triple quadrupole) mass spectrometry (LC-MS/MS) in order to obtain low limits of quantification, high recovery rates and good precisions. The data regarding the determination of the antidiabetic agents in water presented in literature are scarce $[16,17]$. Of our knowledge there is no studies about the antidiabetic's behavior in treatment plants.

Table 1

NAMES, CHEMICAL STRUCTURES AND PHYSICAL PROPERTIES OF SOME ANTIDIABETICS [15, 18]

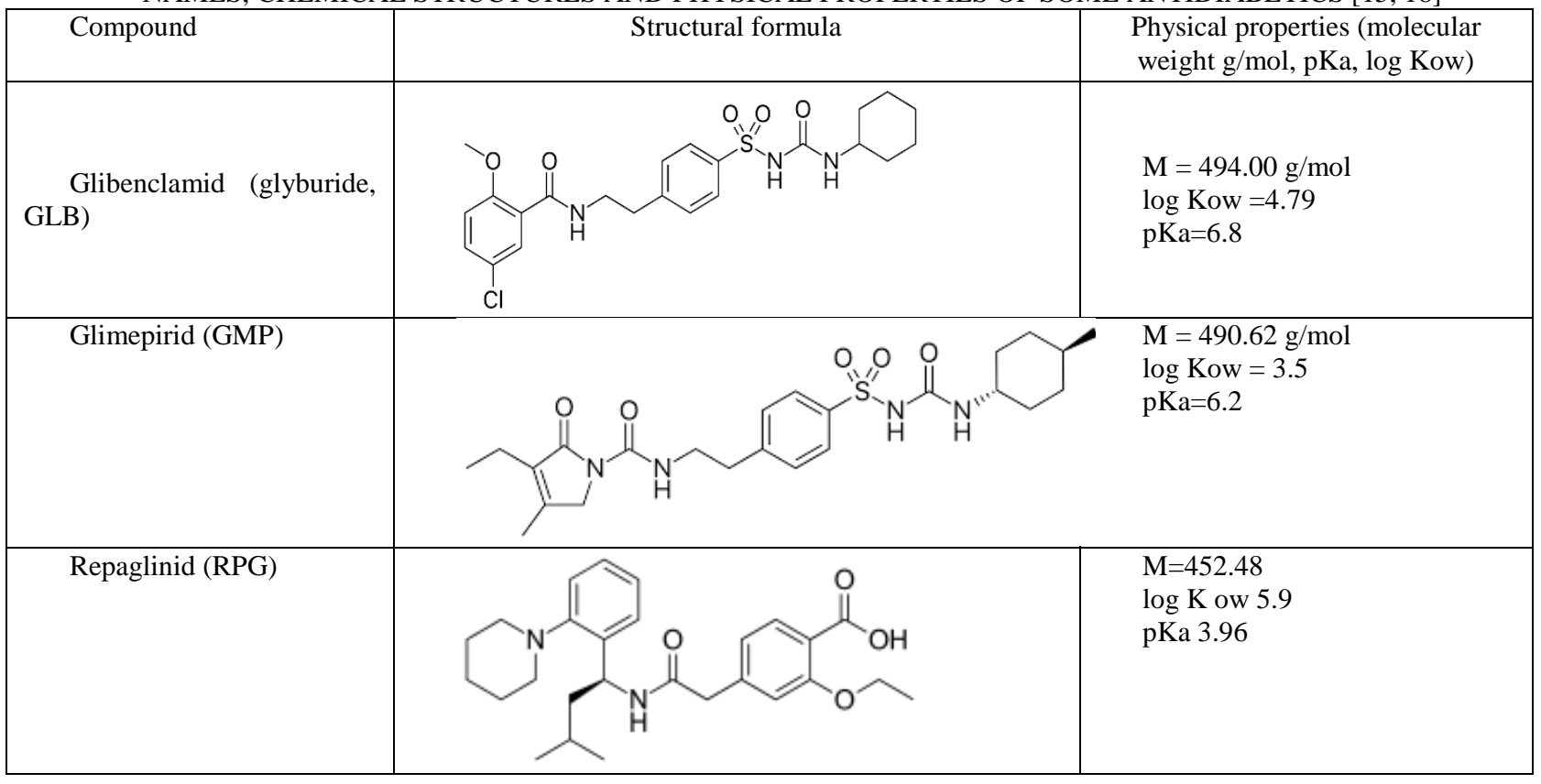

\section{Experimental part}

Reagents and standards

Analytical standards (glyburide/glibenclamid, glimepiride and repaglinide) with purity higher than $99.8 \%$ were received from Sigma Aldrich. Individual stock standard solutions $(500 \mathrm{mg} / \mathrm{L})$ of each compounds were obtained by dissolving the analyte in methanol and stored at $-20^{\circ} \mathrm{C}$. Intermediary standard solution containing $0.5 \mathrm{mg} / \mathrm{L}$ of antidiabetics mixture in acetonitrile was prepared. Further, were obtained five calibration solutions (in LC eluent) in the range of $1-100 \mathrm{ng} / \mathrm{mL}$ by susccesive dilutions of the mixed intermediary standard solution. LC purity acetonitrile (ACN), methanol (MeOH), acetic acid (99.5\%.), formic acid (p.a.), amonium hydroxide 25\%, were aquired from Merck. The LC ultrapure water was prepared with a Millipore water purification system. The Phenomenex Strata X $(0.5 \mathrm{~g}, 6 \mathrm{~mL})$ and Strata C18 $(0.5 \mathrm{~g}, 6 \mathrm{~mL})$ cartridges were used for solid phase extraction of pollutants from environmental samples. The glass microfiber filters $(1.6 \mu \mathrm{m})$ used to filtrate the samples were aqiured from Merck.

\section{Sample preparation}

The influent and effluent water samples were collected from urban and rural WWTPs. The analytes were selective isolated from samples with Thermo Scientific 280 Dionex Autotrace SPE device. First the influent and effluent samples $(250 \mathrm{~mL})$ were filtered by $1.6 \mu \mathrm{m}$ glass microfiber filter to remove suspended mater that may block the SPE cartridges and further the $\mathrm{pH}$ was adjusted to 8.5 with amonium hydroxyde $0.2 \%$. The SPE cartridges were preconditioned sequentially with $2 \times 4 \mathrm{~mL}$ of methanol, $2 \times 4 \mathrm{~mL} \mathrm{NH}_{4} \mathrm{OH}$ in ultrapure water at $\mathrm{pH}$ 8.5. The sample was passed through on Strata C18 cartridges in order to retain the pollutants on octadodecyl silica-C18 adsorbants. Further, the potential interferences were removed from cartridge by washing with $20 \mathrm{~mL}$ of ultrapure water with $\mathrm{NH} 4 \mathrm{OH}$ at $\mathrm{pH} 8.5$. Then cartridges were air-dried for $20 \mathrm{~min}$ and the contaminants are eluted with $2 \times 3 \mathrm{~mL}$ methanol. The organic extracts were evaporated until dry at $40^{\circ} \mathrm{C}$ in water bath under a gentle $\mathrm{N} 2$-gas flow. The obtained residue was dissolved in $1 \mathrm{~mL}$ of ACN: $\mathrm{CH} 3 \mathrm{COOH} 0.04 \%$ (60/40, v/v), initial LC mobile phase. Finally, $10 \mu \mathrm{L}$ of extract was injected in LC-MS/MS. Ultrapure water samples were extracted and analyzed togheter with the samples, as method blanks. 


\section{$L C-Q Q Q-M S$ equipment and conditions}

Detection of antidiabetic drugs in waste water was performed with Agilent 1260 UHPLC (Germany), tandem with triple quadrupole mass spectrometer (Agilent 6410B $Q Q Q$ ). Data acquisition and analysis were performed using Mass Hunter software. The compounds separation was performed on Eclipse C18 column $(100 \times 2 \mathrm{~mm}, 3.4 \mu \mathrm{m})$ from Agilent which was kept at $30^{\circ} \mathrm{C}$. Mobile phase was $0.04 \% \mathrm{CH}_{3} \mathrm{COOH}$ (A) and $\mathrm{ACN}$ (B) 60/40. Separation was done with 0.2 $\mathrm{mL} / \mathrm{min}$ eluent flow by injecting $10 \mu \mathrm{L}$ of standard solution. To increase sensitivity the chromatograms were recorded in MRM mode using negative ionization ESI. As collision gas and nebulizing gas was used Nitrogen. Analytes ionization was performed at $300^{\circ} \mathrm{C}$ and $9 \mathrm{~L} / \mathrm{min}$ nitrogen, 40 psi nebulizer pressure and a capillary voltage of $3500 \mathrm{~V}$. Collision energies, fragmentor voltages were varied to produce the best $\mathrm{S} / \mathrm{N}$ ratio. Optimized working MS parameters are presented in Table 2. For each pollutant there were recorded two transitions between the precursor $[\mathrm{M}-\mathrm{H}]^{-}$ion and the most intense product ions. The MRM transitions (Quantifier for quantitation and Qualifier for confirmation) are presented in Figure 1 for a calibration solution $25 \mathrm{ng} / \mathrm{mL}$ of antidiabetics in mobile phase.

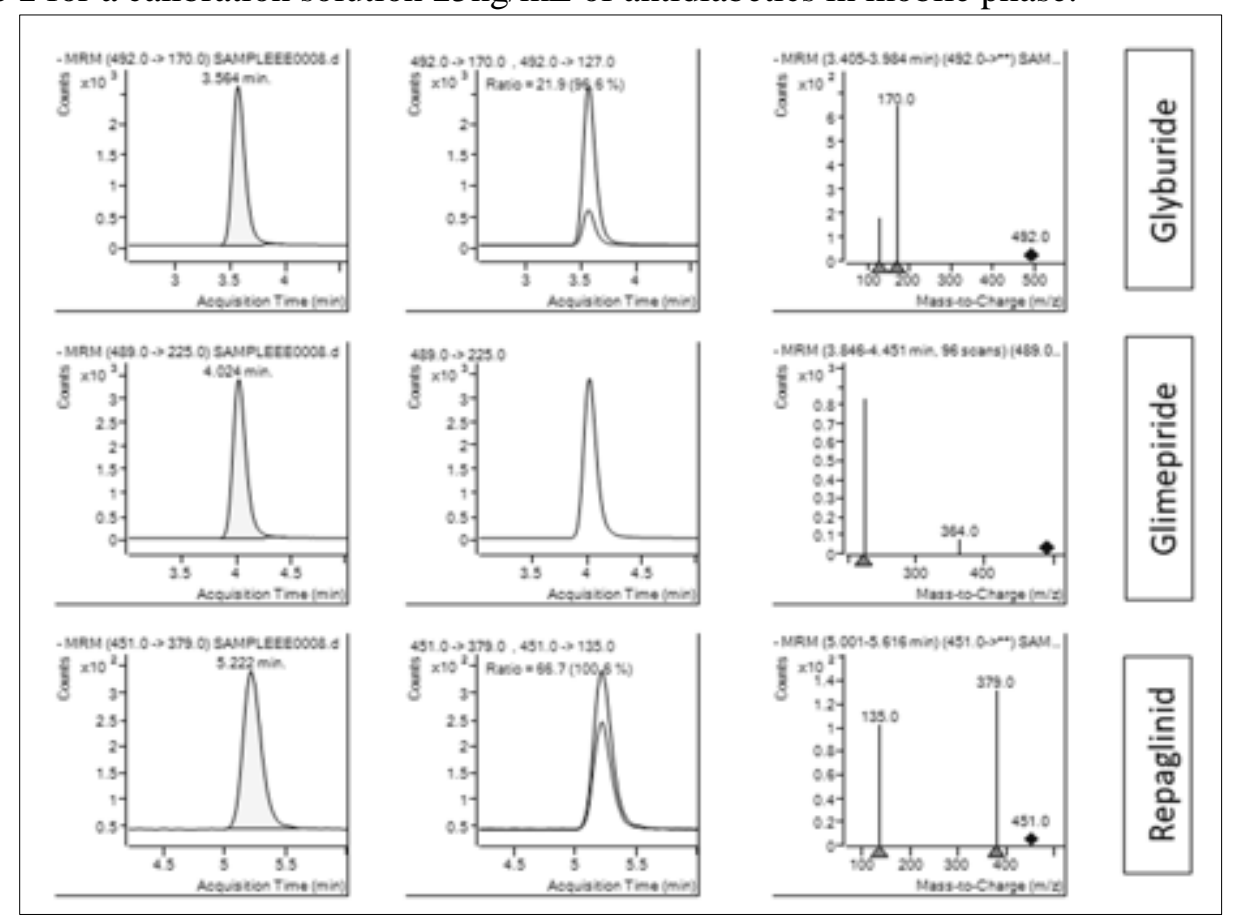

Fig. 1 MRM transitions and mass spectra obtained for a standard solution containing $25 \mathrm{ng} / \mathrm{mL}$ mixed antidiabetics in mobile phase

Table 2

QQQ WORKING PARAMETERS FOR THE 3 ANTIDIABETICS

\begin{tabular}{|c|c|c|c|c|c|}
\hline Compound & $\begin{array}{c}\text { Retention } \\
\text { time }\end{array}$ & $\begin{array}{c}\text { MRM } \\
\text { Tranzition }\end{array}$ & $\begin{array}{c}\text { Fragmentor } \\
\text { voltage } \\
(\mathrm{V})\end{array}$ & $\begin{array}{c}\text { Collision } \\
\text { energy }(\mathrm{V})\end{array}$ & $\begin{array}{c}\text { Dwell } \\
\text { time } \\
(\mathrm{msec})\end{array}$ \\
\hline & & $492 \rightarrow 170$ & 140 & 45 & 60 \\
Glyburid & 3.57 & $492 \rightarrow 127$ & 140 & 40 & 60 \\
\hline Glimepirid & 4.04 & $489 \rightarrow 364$ & 140 & 40 & 60 \\
\hline & & $451 \rightarrow 379$ & 140 & 30 & 60 \\
\hline Repaglinid & 5.22 & $451 \rightarrow 135$ & 160 & 20 & 60 \\
\hline
\end{tabular}

\section{Validation study}

The method was fully validated for waste water samples for the next parameters: linearity, limits of quantitation, intra-day and inter-day precision, accuracy/recoveries. The calibration curves were obtained by analyzing standard solutions at 6 concentrations between 1 and $100 \mathrm{ng} / \mathrm{mL}$. Linearity was accepted if the determination coefficient was higher than 0.99. The LOQ were quantified from the smallest substance concentration in a sample chromatogram for which the signal noise ratio is 10 . For repeatability tests, three identical samples were contaminated with known concentrations of compounds, and analyzed on the same day, while for reproducibility tests, extraction and detection were performed for 3 identically contaminated samples in three days. Thus, the $250 \mathrm{~mL}$ water was spiked with $1 \mathrm{~mL}$ of $25 \mathrm{ng} / \mathrm{mL}$ antidiabetic mixture. Precision of method was assumed if the RSD was smaller than 15\%. The waste water was previously extracted and analyzed and potential antidiabetics were lowered from spiked samples. Accuracy 
was tested also at 100ng/L and the calculated recovery rate was considered acceptable if that ranged between 70 and $120 \%$.

\section{Results and discussions}

\section{$L C$-QQQ parameter improvment}

The working LC-MS parameters that influence the chromatographic determination were optimized in order to obtain the best response. The compounds ionization in negative ESI was studied using two different additives and organic phases. Thus, aqueous formic acid $(0.1 \%)$ and acetic acid $(0.04 \%)$ were tested as additives in mobile phase and acetonitrile or methanol were studied as organic component. For formic acid it was observed a weaker ionization (high noise) and so this component was eliminated for further experiments. As mobile phase the methanol generated a poorer ionization efficiency in comparison with acetonitrile. The sensitivity improved with acetic acid $0.04 \%$ probably because amino groups of the antidiabetic molecules ionizes better under these conditions. On the other hand, the increase of acetic acid concentration to $0.07 \%$ decreased the ionization efficiency by increasing of $\mathrm{S} / \mathrm{N}$ ratio. For the acquisition of data/spectra in full scan mode (MS Scan), MS was programmed to operate in the mass range from 50 to 1000 Dalton. In order to establish the MRM transitions, after obtaining the molecular ions of the compounds from the MS spectra, isolation and fragmentation were made in the collision cell to generate the product ions using the Product Ion Scan. Collision energy (CE) in the range of 5-40 V was tested. It was observed that $\mathrm{CE}$ in the range 20-40V produces the highest S/N MS signal and it was selected to generates the two MRM transition (Table 2, Figure 2a). Also, the fragmentor voltage was varied between $60-180 \mathrm{~V}$ to obtain the best response. The best results were produced with fragmentor energies between 140 and $160 \mathrm{~V}$ (Figure $2 \mathrm{~b}$ ). The MS working selected parameters were: $9 \mathrm{~L} / \mathrm{min}$ gas flow, $300^{\circ} \mathrm{C}$ drying gas temperature, $3500 \mathrm{~V}$ capillary voltage, $40 \mathrm{psi}$ nebulizer pressure, $4 \mathrm{~V}$ cell acceleration voltage.

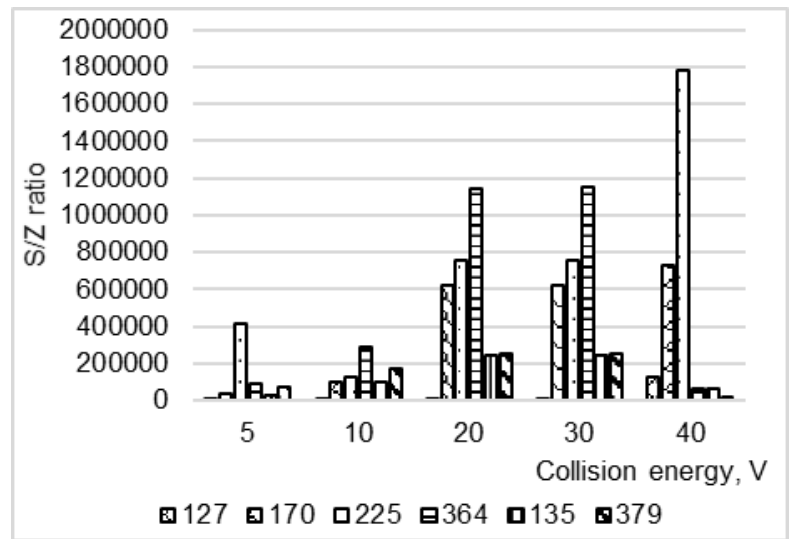

Fig. 2a $\mathrm{S} / \mathrm{N}$ in function of collision energy

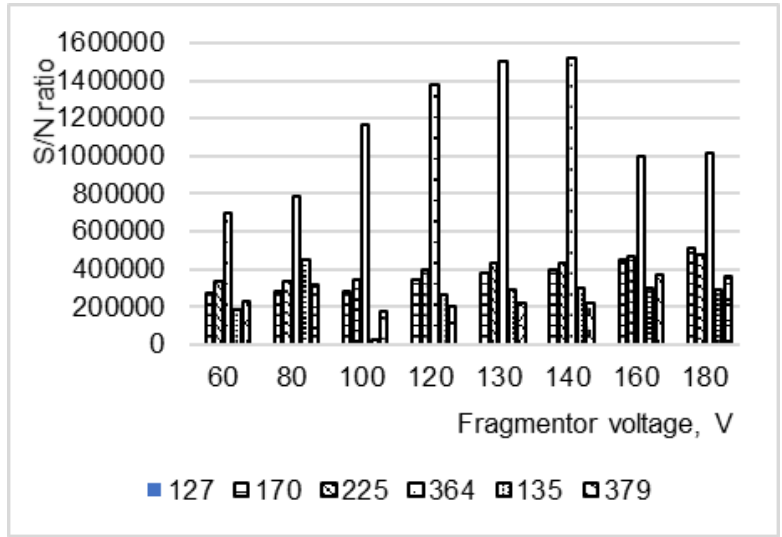

Fig. $2 \mathrm{~b} \mathrm{~S} / \mathrm{N}$ ratio in function of fragmentor voltage

\section{Automated SPE optimization}

The analytical method was optimized using $250 \mathrm{~mL}$ of effluent water spiked at $100 \mathrm{ng} / \mathrm{L}$ for each antidiabetic compound. The type of solid phase material Strata C18 (Phenomenex, $500 \mathrm{mg} / 6 \mathrm{~mL}$ ), Strata C18 cartridges (Phenomenex, $500 \mathrm{mg} / 6 \mathrm{~mL}$ ), sample $\mathrm{pH}$ and use of two elution solvents were studied to improve the extraction efficiency. First, the waste water sample was analyzed and the positive results were subtracted from the values obtained by analyzing the spiked water samples. The recovery rates obtained when using the sorbent Strata X (polymeric sorbent that contains N-vinylpyrrolidone) are lower (25-65.6\%) than the sorbent Strata C18 (72.2-88.2\%) and so the polymer cartridge was disregarded (Figure 3).

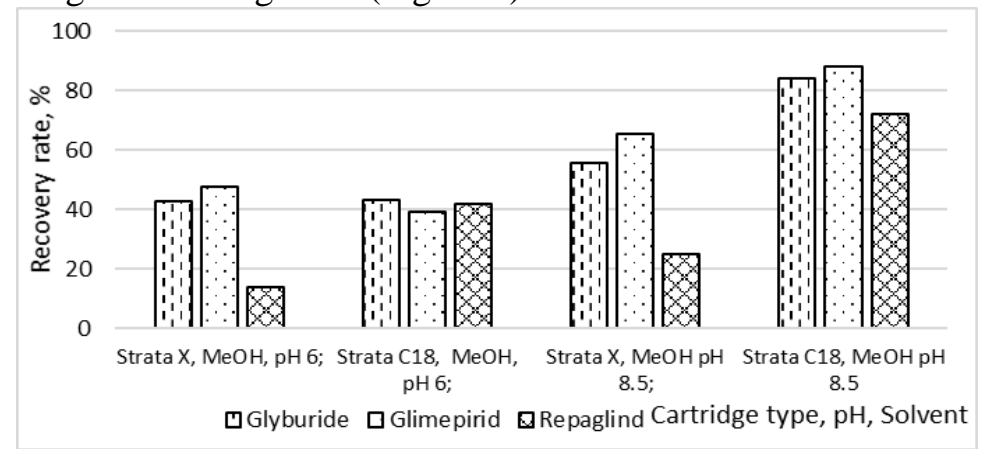

Fig. 3 Recoveries obtained for antidiabetics using Strata X, Strata C18 cartridges, methanol, acetonitrile, $\mathrm{pH}$ adjusting

Also, for elution of the analytes, 2 solvents were tested: methanol and acetonitrile. In the case of acetonitrile, low recoveries were obtained (49.5-63.2\%), but the extraction with methanol allowed to obtain higher yields (72.2-88.2\%). For subsequent studies, methanol was selected as the SPE eluting solvent. Finally, the effect of pH adjustment of samples 
was studied at values7 and $8.5\left(\mathrm{pK}_{\mathrm{a}}\right.$ of analytes varies in the range 3.96-6.80). At neutral $\mathrm{pH} 7$, the recovery rates obtained were poor (39.1-43.4\%), and so we selected to adjust the $\mathrm{pH}$ of the samples to 8.5 with $0.2 \%$ ammonium hydroxide because the adsorption and desorption of the analytes showed maximum efficiency. Lower recoveries were reported by other papers. Thus, for Glyburide Martin et all. reported a recovery of 73\% in WWTP effluent [16]. Considering the $\mathrm{pKa}$ of the three antidiabetics (3.9-6.8), it is known that at neutral $\mathrm{pH}$ of 7, these compounds are completely ionized [15]. Thus, at $\mathrm{pH}$ of 8.5 the recovery was improved probably by increasing of adsorption/desorption on the $\mathrm{C} 18$ material.

\section{Validation of method}

Linear regressions were obtained for each compound in the range of 1-100 $\mathrm{ng} / \mathrm{mL}$ (except repaglinide) with good determination coefficients (0.9927-0.9990). Calibration graphs for Glimepiride are shown in Figure 4. These calibration ranges are comparable with previously reports and indicates the suitability of our method for detection of antidiabetics in water [17].

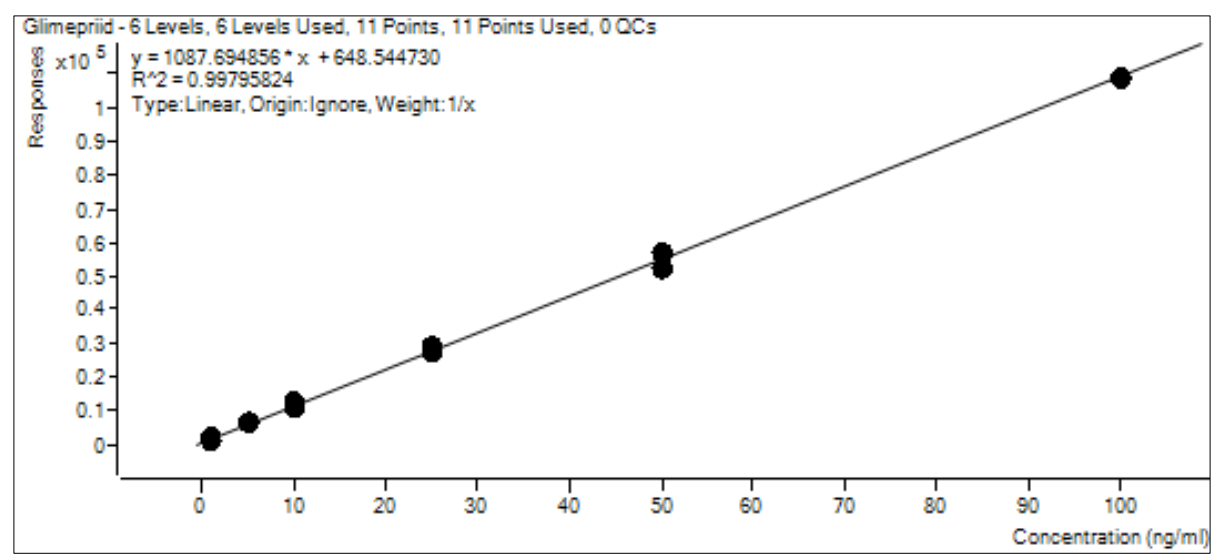

Fig. 4 Calibration graph obtained by LC-MS/MS for glimepiride in the linear range of $1-100 \mathrm{ng} / \mathrm{mL}$

Quantification limits (LOQ) were determined by 5 replicates of effluents samples spiked with the lowest concentration for which the report signal to noise (S/Z) is 10. LOQ were in the range of $0.27-11.1 \mathrm{ng} / \mathrm{L}$ (Table 3). The higher LOQ was obtained by Verlichi et al. in Italy for Gliburyde $6 \mathrm{ng} / \mathrm{L}$ in effluent compared to the current method of $0.6 \mathrm{ng} / 1$ [19]. For glimepiride in Japan, a higher recovery (91.4\%) and a higher LOQ (3ng/L) were obtained in river water than the present method $(88.2 \%, 0.27 \mathrm{ng} / \mathrm{L})$ [17]. Method accuracy expressed as intra-day (3 replicates) and interday (3 days) residual standard deviations were calculated by recoveries tests of the selected analytes in spiked waste water $(100 \mathrm{ng} / \mathrm{L})$. Strata $\mathrm{C} 18$ gave good recoveries for all antidiabetics in the range of 72.2-88.2\%. Intra-day and interday precision were evaluated at a concentration level of $100 \mathrm{ng} / \mathrm{L}$. Repeatability determined as RSD was situated in the range of $6.5-8.4 \%$, while inter-day precision (RSD) was between $11.3 \%$ and $14.6 \%$

Table 3

PERFORMANCE PARAMETERS DETERMINED FOR ANTIDIABETICS IN WASTE WATER SAMPLES

\begin{tabular}{|c|c|c|c|c|c|c|}
\hline Compound & $\begin{array}{c}\text { Calibration } \\
(\mathrm{ng} / \mathrm{mL})\end{array}$ & $\mathrm{R}^{2}$ & $\mathrm{LOQ}$ & $\begin{array}{c}\text { Recovery rate } \\
(\%)\end{array}$ & & \multicolumn{2}{|c|}{\begin{tabular}{c} 
Precision \\
\cline { 5 - 7 }
\end{tabular}} & & & & 83.87 & 6.5 & 11.3 \\
\hline Glyburid & $1-100$ & 0.9927 & 0.62 & 8.5 & 14.6 \\
\hline Glimepirid & $1-100$ & 0.9979 & 0.27 & 88.17 & 7.3 & 13.2 \\
\hline Repaglinid & $5-100$ & 0.9990 & 11.1 & 72.25 & 8.4 & Inter-day precision \\
\hline
\end{tabular}

Matrix effect is a limitation of quantitative analysis that affects the reproducibility and accuracy of methods. Studies performed to evaluate the effect of the matrix have shown that the electrospray ionization source (ESI) is more strongly influenced by the matrix effect due to its ionization mechanism in which the analyte is ionized in the liquid phase before it is released into the gaseous phase. Signal suppression may occur during the entire series of events preceding the access of the analysts to the MS detector. To determine the effect of the loaded water matrix in the mass detector ionization source, the post-extraction addition method was selected. A number of two waste water samples from the influent and effluent, respectively, were subjected to the solid phase extraction process. The obtained extracts were contaminated with a known concentration of analyte mixture $(50 \mathrm{ng} / \mathrm{L})$ in $1 \mathrm{~mL}$ of $\mathrm{MeOH}$ and analyzed. The effect of the matrix in the ionization source was calculated by the ratio of the area of the analytes in the post-SPE contaminated sample (area obtained after the corresponding area of the analytes determined from the uncontaminated sample) to the peak area of a 
standard solution with a concentration identical to the one with which the sample was contaminated. The data obtained for the matrix effect of each analyte are shown in Figure 5.

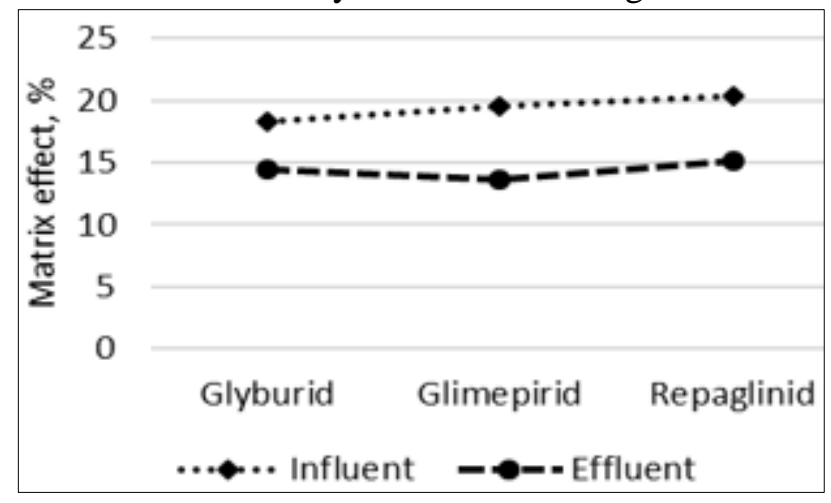

Fig. 5 Matrix effect observed for detection of antidiabetics in waste waters

The obtained values varied in the range of $18.3-20.3 \%$ for the influent and in the range of $13.6-15.2 \%$ for effluent. The matrix effect evaluated in the mass spectrometer ionization source revealed a more pronounced effect of the influence compared to the effluent, the content in organic compounds of this matrix being greater than that of the effluent. The obtained results highlight that the complex matrix analyzed is responsible for both the relatively low extraction yield and the incomplete ionization of the analytes before reaching the MS detector.

Antidiabetics occurrence in WWTPS

A total of 18 influent and effluent samples from 9 WWTPs ( 1 urban and 8 rural from the county of Arad) were analyzed for the detection of the three antidiabetics. The sample waters were composites being taken every hour during 24h. Glimepiride was the most frequent determined being observed in $44.4 \%$ (8/18) of the total samples, followed by the glyburide which was quantified in $22.2 \%(4 / 18)$ of the total samples. The highest concentrations were recorded in urban WWTP in influent (11.5ng/L glyburide and $12.8 \mathrm{ng} / \mathrm{L}$ glimepiride, Figure 6) and in effluent (7.4ng/L glyburide and $6.1 \mathrm{ng} / \mathrm{L}$ glimepiride, Figure 7). The city where the station is located has a population of 422000 inhabitants and an effluent flow of $84000 \mathrm{~m}^{3} / \mathrm{day}$. Repaglinide was not detected in any of samples.

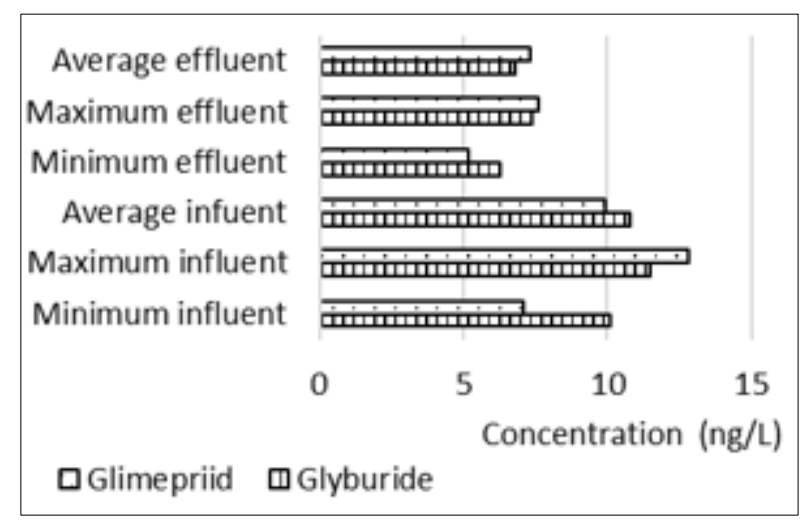

Fig. 6a Antidiabetic concentrations in WWTPs

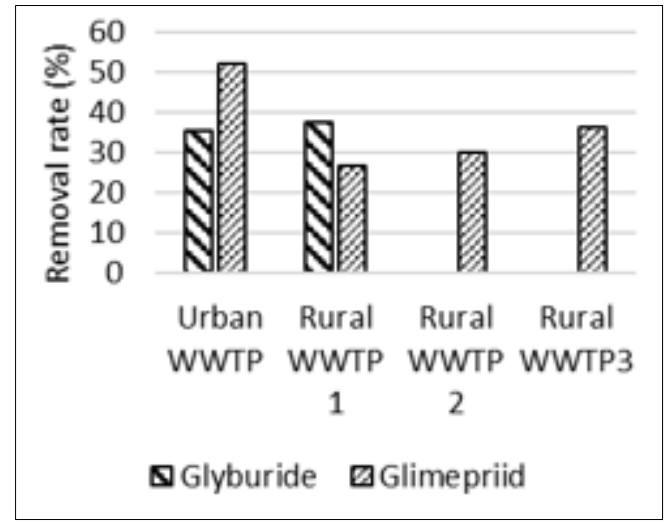

Fig. 6b Antidiabetics removal rate in WWTPs

These values correspond to low or intermediate removal rates of compounds in WWTPs. Thus, in Urban WWTP glimepiride was removed in a proportion of $52.3 \%$ and glyburide in 35.6\%. It was observed that urban WWTP removed the selected contaminants in a proportion higher than rural WWTP. So, Glimepiride was removed in rural WWTP in a range of 26.8-36.1\% and glyburide has a removal rate of 37.6\%. Glyburide removal rates are similar or lower than other reported values in literature (approximatively $45 \%$ in a bioreactor with membrane) [20].
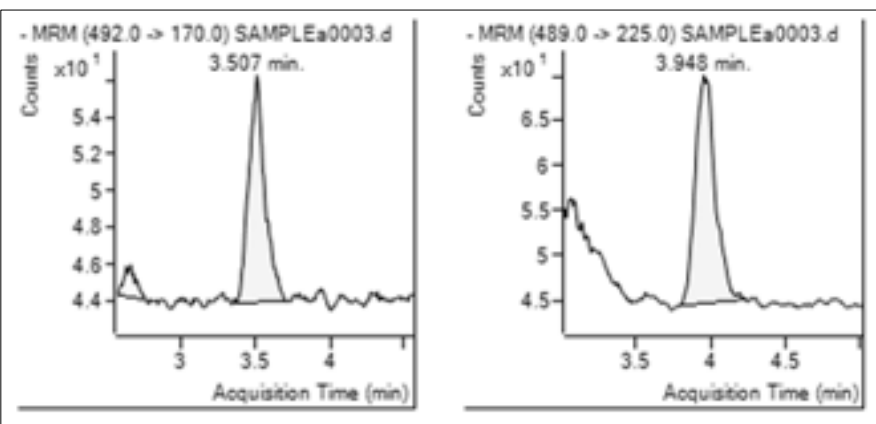

REV.CHIM.(Bucharest) $70 \diamond$ no. $12 \downarrow 2019$
Fig.7 The MRM chromatogram of an urban WWTP sample (effluent) showing detection of glyburide and glimepiride 
Glyburide is a pharmaceutical consumed in high amounts being metabolized by hydroxylation at cyclohexyl moiety [21]. He is urinary excreted as parent compound in proportion of 30-40\%. Glyburide was considered not persistent but observing his log Kow (4.79) it can assume that he is a bio-accumulative compound [22]. Glimepiride was reported to be potential persistent being only partially degraded in soils study (56\%) [23]. Also, this antidiabetic has a bioaccumulative character.

\section{Conclusions}

A SPE-LC/MS/MS method was developed for the detection of three antidiabetics from two chemical classes (sulfonylurea: glyburide/glibenclamide, glimepiride and meglitinide: repaglinide) in wastewater samples. Isolation of compounds was performed by solid phase extraction using Strata $\mathrm{C} 18$ material and methanol as elution solvent. The $\mathrm{pH}$ of sample was adjusted with $\mathrm{NH} 4 \mathrm{OH} 0.2 \%$ at 8.5 value. The performance parameters obtained after all SPE-LC-MS/MS procedure were suitable for trace determination of antidiabetics in WWTP influent and effluent waters. The method gave good recoveries (>72.5\%), low LOQ (0.27-11.1ng/L) for all compounds and good precision values (6.5-14.6\%). The method was applied to detect the analytes in nine WWTPs (one urban and eight rural). In urban WWTP glimepiride was removed in a proportion of $52.3 \%$ and glyburide of $35.6 \%$. It was observed that urban WWTP removed the selected contaminants in a proportion higher than rural WWTP. So, Glimepiride was removed in rural WWTP in a range from 26.8 to $36.1 \%$ and glyburide has a removal rate of $37.6 \%$.

Acknowledgements: The authors acknowledge the financial support offered by The National Research Program Nucleu through contract no 20N/2019, Project code PN 19040101.

\section{References}

1. RICHARDSON, S.D., TERNES, T.A., Anal Chem., 77, no. 12, 2005, p. 3807.

2. MROZIK W., STEFAŃSKA, J. Chemosphere, 95, 2014, p.281.

3. VLAD, A., Al 36-lea Congres Naţional al Societăţii Române de Diabet, Nutriţie şi Boli Metabolice, Sibiu, 2010, p.45.

4. FACHI, M.M., CERQUEIRA, B.L., LEONART, L. P., DE FRANCISCO T.M Gd.., PONTAROLO, R., Plos One, 2016 , p.1.

5.***Official Journal of the European Union, 2018, no. L 141, p. 9., https://eur-lex.europa.eu/legal-content/EN/TXT/PD F/?uri=CELEX: 32018D $0840 \&$ rid $=7$.

6. SCHEURER, M., MICHEL, A., BRAUCH, H. J., RUCK, W., SACHER, F., Water Res., 46, 2012, p. 4790.

7. BROWN A. K., WONG, C.S, J. Cromatogr. A, 1471, 2016, p. 34.

8. MARKIEWICZ, M., JUNGNICKEL, C., STOLTE, S., BIAŁK-BIELINSKA A., KUMIRSKA, J., MROZIK, W., J. Hazard. Ma.t, 324, 2017, p. 428.

9. PAUN, I., IANCU, V.I., CRUCERU. L., NICULESCU. M, CHIRIAC. F.L., PUIU, D.M., MIHALACHE, M., International Symposium the Environment and the Industry, Proceedings Book, 2017, p. 115.

10. IANCU V.-I., PETRE, J., POPESCU, M., G.-L. RADU, International Symposium “The Environment and The Industry”, Proceedings Book, 2018, p. 92.

11. PETRE, J., GALAON, T., IANCU, V. I., NICULESCU, M., International Symposium “The Environment and The Industry”, Proceedings Book, 2017, p. 237.

12. IANCU, V. I., PETRE J., GALAON, T., VASILE, G. G., RADU. G. L., Rev. Chim. (Bucharest), 69, no. 11, 2018 , p. 4148.

13. PAUN, I, IANCU. V. I., CRUCERU. L., NICULESCU. M., CHIRIAC. F. L., Rev. Chim. (Bucharest), 69, no. 1, 2018 , p. 27.

14. PETRE, J., GALAON, T., IANCU, V.I., VASILE, G.G., STANESCU, E., PASCU, L.F., SIMION, M., CRUCERU, L., Rev. Chim. (Bucharest), 67, no. 8, 2016, p. 1436.

15. REMKO, M., J. MOL. STRUCT-THEOCHEM, 897, 2019, p. 73.

16. MARTÍN, J., BUCHBERGER, W., SANTOS, J.L., ALONSO, E., APARICIO, I., J. Chromatogr. B, 895-896, 2012 , p. 94.

17. KAI, S., ISHIKAWA K., ITO, H., OGAWA, T., YAMASHITAM H., NAGATA, Y., KANAZAWA, H., Chromatography, 36, 2015 , p. 19.

18. *** https://pubchem.ncbi.nlm.nih.gov/

19.. VERLICHI, P., AUKIDY, M.A., GALLETI, A., PETROVIC. M., BARCELOR, D., Sci. T. Environ., 430, 2012 , p. 109.

20. RADJENOVIC, J. PETROVIC, M. BARCELO, D., Anal. Bioanal. Chem, 387, no. 4, 2007, p. 1365.

21. KRENTZ, A.J., BAILEY, C.J., Drugs, 65, no. 3, 2005, p. 385.

22. SCHEURER, M., SACHER, F., BRAUCH, H. J., J. Environ. Monit., 11, 2009, p. 1608.

23.. MARKIEWICZ, M., JUNGNICKEL, C., STOLTE, S., BIALK-BIELINSKA, A., KUMIRSKA J., MROZIK, W., J. Hazard. Mater., 324, pt. B, 2017, p. 428.

Manuscript received: 31.07.2019 
